\title{
Low biochemical variability in European fallow deer (dama dama L.): natural bottlenecks and the effects of domestication
}

\author{
Ettore Randi and \\ Marco Apollonio
}

Istituto Nazionale di Biologia della Selvaggina, Via Cà Fornacetta, 9, 40064 Ozzano dell'Emilia (Bo), Italy.

Tissue and blood samples from 180 fallow deer (Dama dama L.) belonging to an Italian free-ranging population were studied for biochemical variability by means of cellulose acetate and polyacrylamide gel electrophoresis. The 51 putative genetic loci successfully resolved showed a very low level of variability $(P=0 \cdot 020, H=0 \cdot 006)$ in accordance with previously reported data on British and West German populations. That low biochemical polymorphism in European fallow deer populations is discussed taking into account the effects of natural bottlenecks and of domestication.

\section{INTRODUCTION}

The fallow deer (Dama dama L.) during the last Interglacial was distributed in Europe and in the Mediterranean region (Southern Europe, NorthWestern Africa, Asia Minor, Iran) (Nowak and Paradiso, 1983). Two subspecies are recognized: the Persian fallow deer ( $D . d$. mesopotamica), actually reduced to a very small endangered population in Iran (Heidemann, 1987) and the European fallow deer $(D . d$. dama), world wide distributed, with an estimated total population of about 200,000 (Heidemann, 1987).

The present distribution is essentially nonnatural. At the end of the last Pleistocene glaciation (c. 10,000 BP) all European fallow deer populations probably became extinct as suggested by the lack of any fossil evidence until the early Neolithic (4000 BP) (Chapman and Chapman, 1975). Starting from the surviving Mid Eastern (probably Turkish) wild populations, the progeny of tamed animals was later reintroduced in Europe (by the Phoenicians and the Romans) and in Britain (by the Normans) (Haltenorth, 1959). Founding and spreading of free-ranging and wild-living populations occurred during historical times, particularly in regions with temperate climate, although the present world population is not so large as many other wild or introduced Cervidae populations (Pemberton and Smith, 1985).

Phenotypic variability and coat colour polymorphisms are well known in the European fallow deer (Chapman and Chapman, 1975). Moreover the reproductive behaviour of this species suggests a possibility of genetic differentation between herds (Smith, 1979). High variance of reproductive success among males is observed in polygynous ungulates, and local populations are often subdivided as a consequence of the traditional use of different leks by subpopulations. When the dominant mating system of a population is by lekking, divergence of morphological and behavioural characters between subpopulations is observed in ungulates (Buechner and Roth, 1974). Consequently, the very low (if any) level of biochemical polymorphism electrophoretic studies detected in several British populations (Pemberton and Smith, 1985) and in a German one (Hartl et al., 1986) was somewhat unexpected.

In this paper an electrophoretic survey on a sample of fallow deer from an Italian free-ranging population is presented. The results are discussed in the light of the genetic consequences of domestication and taking into account the effects of natural bottlenecks during the late Pleistocene evolution of this species.

\section{MATERIAL AND METHODS}

Tissues (liver, kidney, heart) were obtained from 180 fallow deer shot during annual selective cullings in 1985 and 1986 at the San Rossore Preserve (Pisa, Tuscany). Whole blood samples were taken 
from 60 of these specimens by the opening of the cardiac cavity (using a 2.7 per cent EDTA. $\mathrm{Na}_{2}$ anticoagulant solution). Only the animals shot not more than 3-4 hours before were sampled. Tissues, sera and red blood cells ( $\mathrm{Rbc}$ ) (separated after $10 \mathrm{~min}$ of centrifugation at $2000 \mathrm{rpm}$ ) were deep frozen $\left(-80^{\circ} \mathrm{C}\right)$ until the analysis.

Vertical polyacrylamide gel (VPAGE) and cellulose acetate membrane (CAM) electrophoresis were performed to resolve a total of 51 putative genetic loci (table 1).

\section{RESULTS}

VPAGE with the discontinuous system of Davis (1964) allows a clear resolution of at least 11 putative loci in serum, including slow $\alpha$-macroglobulins, transferrin, hemoglobins, albumin and post-albumin. Electrophoretic variation was observed at a single protein zone, in the slow $\alpha$-macroglobulin region, not interpretable as a genetic polymorphism, a conclusion in agreement with Pemberton and Smith's (1985) report. Five zones of esterase activity ( $\alpha$-naphtyl-acetate staining) were clearly resolved working with a Tris- borate $p$ H 8.9 buffer (McLellan et al., 1981). The three fast bands showed sensitivity to eserine sulphate inhibition. All the systems were monomorphic. Serum peroxidase (POX) activity was detected by staining with tetrametilbenzidine $/ \mathrm{H}_{2} \mathrm{O}_{2}$ solutions. Excluding three bands clearly associated with the presence of hemoglobin in sera (as stated by running hemolysed v.s. non-hemolysed sera), at least three zones showing POX activity were resolved. Any polymorphism was detected. Among the Rbc enzymes only the locus for catalase (CAT) showed an electrophoretic polymorphism, although the electromorphs were poorly resolved. Following Hartl et al.'s (1986) suggestion, this locus appears to be genetically polymorphic in the Italian sample (table 2) as well as in the German one.

Among the tissue enzymes electrophoretic variation was detected only at the locus liver POX. Beside the contaminant hemoglobin tracks, three other different POX zones stained, the second of which (in order of electrophoretic mobility) showed three electromorphs roughly interpretable as fast and slow homozygotes and as a possible heterozygote with two (monomeric protein) or three (dimeric protein) bands. The genotype

Table 1 Loci studied in an Italian population of fallow deer

\begin{tabular}{|c|c|c|c|c|}
\hline Protein & $\begin{array}{l}\text { E.C. } \\
\text { number }\end{array}$ & $\begin{array}{l}\text { Number } \\
\text { of loci }\end{array}$ & $\begin{array}{l}\text { Tissue } \\
\text { (a) }\end{array}$ & $\begin{array}{l}\text { Method } \\
\text { (b) }\end{array}$ \\
\hline Serum proteins $=\mathrm{Pt}$ & & 11 & $\mathbf{S}$ & VPAGE \\
\hline Esterase $\mathrm{D}=\mathrm{ESD}$ & 3.1.1.1 & 1 & $\mathbf{R}$ & CAM \\
\hline Peroxidase $=\mathrm{POX}$ & 1.11.1.7 & 6 & $\mathrm{~S}, \mathrm{~L}$ & VPAGE \\
\hline Phosphoglucose isomerase $=$ PGI & 5.3 .1 .9 & 1 & $\mathrm{~L}, \mathrm{R}$ & CAM \\
\hline Glucose-6-phosphate dehydrogenase $=$ G6PD & 1.1.1.49 & 1 & $\mathrm{~L}$ & CAM \\
\hline Phosphoglucomutase = PGM & 2.7.5.1 & 2 & $\mathrm{~L}, \mathrm{H}$ & CAM \\
\hline Malate dehydrogenase $=\mathrm{MDH}$ & 1.1.1.37 & 2 & $\mathrm{R}, \mathrm{L}$ & VPAGE \\
\hline Superoxidismutase $=$ SOD & 1.1.5.11 & 2 & $\mathrm{R}, \mathrm{L}$ & VPAGE \\
\hline 6-Phosphogluconate dehydrogenase $=6 \mathrm{PGD}$ & 1.1.1.44 & 1 & $\mathrm{~L}$ & CAM \\
\hline Lactate dehydrogenase $=\mathrm{LDH}$ & 1.1.1.27 & 2 & $\mathrm{R}, \mathrm{L}$ & VPAGE \\
\hline Malic enzyme $=\mathrm{ME}$ & 1.1.1.40 & 1 & L & VPAGE \\
\hline Adenylate kinase $=\mathrm{AK}$ & 2.7.4.3 & 2 & $\mathrm{R}, \mathrm{L}$ & CAM \\
\hline Acid phosphatase $=\mathrm{ACP}$ & 3.1.3.2 & 2 & $\mathrm{R}, \mathrm{L}$ & CAM \\
\hline Alcohol dehydrogenase $=\mathrm{ADH}$ & 1.1.1.1 & 3 & L & CAM \\
\hline Catalase $=$ CAT & 1.11.1.6 & 1 & $\mathrm{~L}$ & VPAGE \\
\hline Isocitrate dehydrogenase $=$ IDH & 1.1.1.42 & 1 & $\mathbf{L}$ & CAM \\
\hline Aspartate aminotransferase $=\mathrm{AAT}$ & 2.6.1.1 & 1 & $\mathbf{L}$ & CAM \\
\hline Peptidase $=$ PEP & 3.4.1.1 & 3 & $\mathrm{~L}$ & VPAGE \\
\hline Sorbitol dehydrogenase $=\mathrm{SDH}$ & 1.1.1.14 & 1 & $\mathrm{~L}$ & CAM \\
\hline Esterase $=\mathrm{ES}$ & 3.1 .1 .1 & 5 & $\mathbf{S}$ & VPAGE \\
\hline Amylase $=\mathrm{AMY}$ & 3.2.1.1 & 2 & $\mathbf{S}$ & VPAGE \\
\hline
\end{tabular}

(a) Tissues: $\mathrm{S}=$ serum, $\mathrm{L}=$ liver, $\mathrm{H}=$ heart, $\mathrm{R}=$ red blood cells.

(b) VPAGE = vertical polyacrylamide gel electrophoresis; CAM = cellulose acetate membrane electrophoresis. The electrophoretic methods and the staining recipes were modified form: Harris and Hopkinson, (1976); Davis, (1964); Meera-Khan et al., (1982). 
Table 2 Presumed genetic polymorphisms at the CAT POX loci in the Italian sample of fallow deer

\begin{tabular}{llllllll}
\hline & \multicolumn{3}{l}{ Genotypes } & & & \multicolumn{2}{l}{ Allele frequencies } \\
\cline { 2 - 4 } Locus & $A A$ & $A B$ & $B B$ & & $p(a)$ & $p(b)$ & (a) \\
\hline CAT & 120 & 49 & 11 & & 0.80 & 0.20 & $4.05 \mathrm{~ns}$ \\
POX & 88 & 45 & 47 & & 0.61 & 0.39 & $41.47^{* *}$ \\
\hline
\end{tabular}

(a) The agreement with the expected Hardy-Weinberg genotype frequencies was tested using the $\mathrm{Li}$ and Horvitz's (1953) formula. ns = not significant; $* *=P \leqslant 0.01$.

frequencies at this locus were not in Hardy-Weinberg equilibrium as a possible consequence of the poor resolution of the electromorphs or as a statement of non-genetic variation (table 2). Family data should be needed to be certain of the genetic basis of this presumptive polymorphism. Assuming that they are both genetic polymorphisms, we obtain the following values of per cent of polymorphism and of mean heterozygosity: $P=$ $0.039, H=0.016$, but in the more strongly supported case that only the variation at the CAT-locus is genetic, such values come down to: $P=0.020$ and $H=0.006$, suggesting the existence of a very low level of genetic (electrophoretic) variability at the structural gene loci in that Italian fallow deer population.

\section{DISCUSSION}

Two studies on European fallow deer population genetics by means of multilocus gel electrophoresis have previously been published.

Pemberton and Smith (1985) screening 30 loci on a minimum of 88 individuals for locus, showed that samples from 37 populations in Britain were lacking of any biochemical polymorphism. Hartl et al., (1986) by studying 15 loci in samples of 18-118 individuals from a fenced West-German population, found an electrophoretic polymorphism (at the CAT locus) interpretable in terms of genetic polymorphism. In this study (51 loci resolved in 60 blood and 180 tissue samples from a Central Italy free-ranging population), we can confirm the previously detected CAT polymorphism, while electrophoretic variation at a liver POX locus was difficult to interpret in genetic terms. In conclusion, European fallow deer populations appear to show a very low level of genetic (electrophoretic) variation. Heterozygosity values range from $H=0.0$ (Pemberton and Smith, 1985) to $H=$ 0.006 (this study). Per cent of polymorphic loci range from $P=0.0$ (Pemberton and Smith, 1986) to $P=0.020$ (this study). Although samples from different geographic populations or the analysis of a larger set of loci, could possibly reveal more genetic variation, European fallow deer appears to belong to the bunch of nearly monomorphic large mammals (Waine et al., 1986).

No selectionist (adaptive) theory can explain this low level of genetic variation (Pemberton and Smith, 1985). From the review by Nevo et al., (1984) it is apparent that mammals have the lowest mean $H$ and $P$ values among all other taxonomic groups, but none of the main trends in genetic variability shown in mammals seems to be appropriate to the observed low fallow deer polymorphism. Fallow deer is not an arctic, a specialist or an endemic species, although its natural range has been dramatically restricted following the climatic changes during the last Pleistocene glaciation. It is a medium body size species and low genetic variability is not expected from this point of view, although the body size hypothesis (Selander and Kaufman, 1973) is not fully supported from data on Cervidae (Baccus et al., 1983) and on mammals in general (Wooten and Smith, 1985). The actual population size of a species (Nevo et al., 1984) is a highly significant predictor of genetic variation: $H$ and $P$ are smaller in small than in medium and large populations. A demographic explanation, together with the evaluation of the time since the last bottleneck (Soulé, 1977) has to be taken into account.

The recent demographic history of the Italian and European fallow deer populations is mainly related to their human domestication. After the last glaciation, fallow deer populations were confined to the Middle East by cold climate consequences. The Phoenicians who utilized fallows as cult/sacrifice animals, tamed and reintroduced the species in Europe starting from their Western Mediterranean colonies, as is well-documented by bone and skull remains (Haltenorth, 1959). Such founder herds were probably very small because they had to be shipped from Lebanon to North- 
Africa, Sardinia, Spain and France. The Romans also contributed to fallow deer spreading in Europe. The population we have studied probably came from Sardinia where the largest Italian fallow deer population lived until 1977 and where there were many Phoenician settlements. The natural as well as the human-caused bottlenecks were very recent and possibly very strong. From the theoretical background (Nei et al., 1975) the expected bottleneck effects are:

(1) a fast decline of $H$ values until a minimum is reached, that is correlated with the number of founders $(\mathrm{Ne})$ and the intrinsic growth rate ( $r)$. If $r$ is low, the minimum $H$ value ( $H$ min) is about 0.065 of the parental population value; if $r$ is very large then $H$ min is about $0 \cdot 65$, with $N e=2$. Assuming the mean equilibrium $H$ value of a Cervidae population is around 0.040 (Randi, submitted) then the expected $H$ min values after a bottleneck are:

(a) $0.04 \times 0.065=0.0026(\mathrm{Ne}=2, r=$ low $)$

(b) $0.04 \times 0.65=0.026(\mathrm{Ne}=2, r=h i g h)$

The value $H=0.0026$ is the expected value more similar to the observed $H=0.006$. It is of course improbable that domesticated European herds of fallow deer started from a single pair, but a story of prolonged inbreeding and low intrinsic growth rate following the domestication is possible. With $\mathrm{Ne}=10$ the slowdown of $H$ is smaller, ranging from 0.93 (for high $r$ values) to 0.59 (for low $r$ values) of the parental value. Then the expected $H$ values after a bottleneck are:

(a) $0.93 \times 0.04=0.037(\mathrm{Ne}=10, r=$ high $)$

(b) $0.59 \times 0.04=0.024(N e=10, r=$ low $)$, absolutely larger than the empirical value.

(2) After the decline, $H$ min starts to increase in parallel with population size, but a number of generations in the order of the reciprocal of the mutation rate (about $2 \times 10^{-6}, \mathrm{Nei}, 1975$ ) is required to restore the original level. If domestication started about $4000 \mathrm{BP}$, it is probable that the present fallow deer populations retain a level of $H$ close to the miminum after the bottleneck. A strong decrease of $H$ following the last Pleistocenic glaciation natural bottleneck has then to be taken into account: it is realistic to think that the parental $H$ value was much lower than $0 \cdot 040$.

(3) After a bottleneck there is a loss of alleles, especially rare alleles, so the $P$ value decreases. While the population size is small, mutational input is low so that the $P$ and $H$ values increase very slowly (Nei et al., 1974). Theoretical studies by Maruyama and Fuerst
(1984, 1985), describe the patterns of loss of alleles in small populations. After a bottleneck (natural as well as during the initial process of domestication) it is not probable that the loss of alleles follows an equilibrium rate (equilibrium presumes demographic stability, Fuerst and Maruyama, 1986). In such a situation the allele frequency distribution is not normal, but $\mathrm{J}$-shaped, particularly in populations with average heterozygosity lower than $0 \cdot 05$. The relatively large group of low frequency alleles will be easily lost through genetic drift. The small group of high frequency alleles will be retained after a bottleneck, irrespective of sample size. Two consequences are expected. First, the loss of rate alleles does not lower the average heterozygosity values of the sampled groups; second, if several groups are sampled from the same population, it is likely they are genetically similar (i.e., monomorphic at the majority of loci where rare alleles are lost, and polymorphic at the few highly heterozygous ones (Huettel, et al., 1980). That model fits fairly well to the observed fallow deer genetic structure: no rare allele was found in three European populations; the CAT presumed polymorphisms were conspicuous, with single locus values ranging from $H=0.27$ (Hartl et al.) to $H=0.38$ (this study). The German and the Italian populations show similar allele frequencies at this locus. Similar bottleneck effects have indeed affected the genetic structure of some Cervidae species like Sika deer introduced in the U.S.A. (Feldhamer et al., 1982), and Iceland Reindeer (Roed et al., 1985).

Although the prehistoric domestication processes are unknown, it is easy to suppose a very "naif" demographic and genetic management (Foose, 1983):

(1) the founder domesticated population is to be supposed to have a small or very small effective size $(\mathrm{Ne})$;

(2) strong family selection for tameness could have been followed, with repeated failures of herds to reproduce in captivity. Artificial selection for tameness and possibly for coat colour choice could have speeded up the inbreeding rate;

(3) possible subdivision of herds (probably following maternal lineages: a female with her litters) without gene flow among herds;

(4) demographic instability of the managed populations with average $\mathrm{Ne}$ over a number of 
generations consequently moving toward minimum values and the rate of loss of alleles due to drift close to maximum values. Effective population size $(\mathrm{Ne})$ is almost always less than the actual number of breeding adults and demographic fluctuations from generation to generation can further lower its value. In fact, the average $\mathrm{Ne}$ over generations fluctuating in size is not the arithmetical, but the harmonic mean of the $\mathrm{Ne}$ of each generation (Frankel and Soulé, 1981). This hinders the effect of the intrinsic growth rate and maximizes the loss of genetic variability by drift.

Moreover it is possible the high extinction rates that European fallow deer populations underwent during glaciations have contributed to erode genetic variability from the surviving wild populations. As Geist (1987) states, the fallow deer is the last living species of the mid-and late-Pleistocene Megacerinae deer, a very speciose lineage with many short-lived species that arose and became extinct during half a million years. It is strongly supposed from data on Cervidae evolution (Randi, submitted) that natural populations belonging to recent and speciose lineages may retain very low levels of genetic variability. Several demographic crises, as warded by repeated dispersal-extinction cycles during Megacerinae lineage evolution, could have preceded and possibly driven fallow deer speciation, resulting in a surviving post-glacial wild population with very low genetic variability. Several founding events probably happened during the recent history of European fallow deer (small domesticated herds in the Middle East, small herds diffused in the Mediterranean region, small numbers of founders returned to the wild), leading to a low mean Ne value over a number of generations and to an extended erosion of variability by genetic drift. It is also possible that strong directional selection underwent during speciation (Geist, 1987) as well as selection against detrimental recessive alleles following the raising of inbreeding in the domestic or semi-wild populations.

The present fallow deer populations seem to be able to reach good demographic levels and wide expansions in several habitats. But the story of the species looks like the tale of Noah's Ark survivors and if the structural gene loci monomorphisms do reflect a general lack of genetic variability, then the future of the fallow deer, in an evolutionary time frame, could be at risk.

Acknowledgments We wish to thank the Director of the Tenuta Presidenziale di San Rossore (Pisa, Tuscany) for the helpful collaboration in sampling. Ms D. Matteucci and Dr L. Rigacci helped us in the laboratory analysis.

\section{REFERENCES}

BACCUS, R., RYMAN, N., SMITH, M. N., REUTERWALL, C. AND CAMERON, D. 1983. Genetic variability and differentiation of large grazing mammals. J. Mammal., 64, 109-120.

BUECHNER, H. K. AND ROTH, D. H. 1974. The lek system in Uganda Kob Antelope. Amer. Zool., 14, 145-162.

CHAPMAN, D. AND CHAPMAN, N. 1975. Fallow Deer: Their History, Distribution and Biology. Dalton, Lavenham.

DAVIS, B. J. 1964. Disc electrophoresis. II. Method and application to human serum proteins. Ann. N.Y. Acad. Sci., 121, 404-427.

FELDHAMER, G. A., MORGAN, R. P., MCKNEOWN, P. E. AND CHAPMAN, J. A. 1982. Lack of polymorphism in liver and muscle enzymes from Sika deer (Cervus nippon). J. Mammal., 63, 512-514.

FOOSE, T. J. 1983. The relevance of captive populations to the conservation of biotic diversity. In Schonewald-Cox, C. M., Chambers, S. M., MacBride, B. and Thomas, W. L. (eds) Genetics and Conservation, Benjamin Cummings, Menlo Park, pp. 374-401.

FRANKEL, O. D. AND SOULÉ, M. E. 1981. Conservation and Evolution. Cambridge University Press, Cambridge.

FUERST, P. A. AND MARUYAMA, T. 1986. Considerations on the conservation of alleles and genic heterozygosity in small managed populations. Zoo Biol., 5, 171-179.

GEIST, V. 1987. On speciation in Ice Age mammals, with special reference to cervids and caprids. Can. J. Zool., 65, 10671084.

HALTENORTH, T. 1959. Beitrag zur kenntnis des Mesopotamischen Damhirsches-Cervus (Dama) mesopotamicus Brooke, 1875-und zur stammes- und verbreitungsgeschichte der Damhirsche Allengemein. Saugetierk. Mitt. $B d$ VIII, Sonderheft, 1-89.

HARRIS, H. AND HOPKINSON, D. A. 1976. Handbook of Enzyme Electrophoresis in Human Genetics. North-Holland Publishing Co., Amsterdam.

HARTL, G. B., SCHLEGER, A. AND SLOWAK, M.1986. Genetic variability in fallow deer, Dama dama L. Anim. Genet., $17,335-341$.

HeIdemanN, G. 1987. Status of Turkish fallow deer (Cervus dama dama). Int. Symp. Wildlife Fauna in Turkey and in the Balkan Countries. CIC. Istambul.

HUETTEL, M., FUERST, P. A., MARUYAMA, T. AND CHAKRABORTY, R. 1985. Genetic effects of multiple bottlenecks in the Mediterranean fruit fly (Ceratitis capitata). Genetics, 94, s47-s 48 .

LI, C. C. AND HORVITZ, D. G. 1953. Some methods of estimating the inbreeding coefficient. Amer. J. Hum. Genet., 5, 107-117.

MARUYAMA, T. AND FUerst, P. A. 1984. Population bottlenecks and nonequilibrium models in population genetics. I. Allele number when populations evolve from zero variability. Genetics, 108, 745-763.

MARUYAMA, T. AND FUerst, P. A. 1985. Population bottlenecks and nonequilibrium models in population genetics. II. Number of alleles in a small population that was formed by means of a recent bottleneck. Genetics, 111, 675-689.

MCLELlAN, T. AND RAMSHAW, J. A. M. 1981. Serial electrophoretic transfers: a technique for the identification of numerous enzymes from single polyacrylamide gels. Biochem. Genet., 19, 647-654. 
MEERA KHAN, P., RIJKEN, H., WIJNEN, J. T., WIJNEN, L. M. M. AND DE BOER, L. E. M. 1982. Red cell enzyme variation in the orangutan: electrophoretic characterization of 45 enzyme systems in Cellogel. In De Boer, L. E. M. (ed.) The Orangutan. Its Biology and Conservation, $\mathrm{Dr} \mathrm{W}$. Junk Publ., The Hague, pp. 61-108.

NEI, M., MARUYAMA, T. AND CHAKRABORTY, R. 1975. The bottleneck effect and genetic variability in populations. Evolution, 29, 1-10.

NEI, M. 1975. Molecular Population Genetics and Evolution. North-Holland. Amsterdam.

NEVO, E., BEILES, A. AND BEN-SHLOMO, R. 1984. The evolutionary significance of genetic diversity: ecological, demographic and life history correlates. In Mani, G. S. (ed.) Evolutionary Dynamics of Genetic Diversity. Lecture Notes in Biomathematics, Springer-Verlag, Berlin, pp. 13213.

NOWAK, R. M. AND PARAdISO, J. L. 1983. Mammals of the World. Vol II. Johns Hopkins Univ. Press, Baltimore and London.

PEMBERTON, J. M. AND SMITH, R. H. 1985. Lack of biochemical polymorphism in British fallow deer. Heredity, $55,199-207$.
RANDI, E. 1988. Genetic variability in Cervidae (Arctyodactyla) and the Ice Age theory of mammals evolution. Submitted.

ROED, K. H., SOLDAL, A. V. AND THORISSON, S. 1985. Transferrin variability and founder effect in Iceland reindeer, Rangifer tarandus L. Hereditas, 103, 161-164.

SELANDER, R. K. AND KAUFMAN, D. W. 1973. Genic variability and strategies of adaptation in animals. Proc. natl. Acad. Sci. U.S.A., 70, 1875-1877.

SMITH, R. H. 1979. On selection for inbreeding in polygynous animals. Heredity, 43, 205-211.

SOULÉ, M. 1977. Allozyme variation: its determinants in space and time. In Ayala, R. J. (ed.) Molecular Evolution, Sinauer Ass., Massachusetts, pp. 60-77.

WAINE, R. K., FOREMAN, L., NEWMAN, A. K., SIMONSON J. M. AND O'BRIEN, S. J. 1986. Genetic monitors of zoo populations: morphological and electrophoretic assays. Zoo Biol, 5, 215-232.

WOOTEN, M. C. AND SMITH, M. H. 1985. Large mammals are genetically less variable? Evolution, 39, 210-212. 